\title{
1 Frontline healthcare workers' knowledge and perception of 2 COVID-19 and willingness to work during the pandemic in 3 Nepal: a nationwide cross-sectional web-based study
}

5 Dipak Prasad Upadhyaya ${ }^{1,2 \pi}$, Rajan Paudel ${ }^{2 \pi}$, Daniel J. Bromberg ${ }^{3,4}$, Dilaram Acharya ${ }^{5}$, Kaveh 6 Khoshnood $^{6}$, Kwan Lee ${ }^{5}$, Ji-Huyuk Park ${ }^{5}$, Seok-Ju Yoo ${ }^{5}$, Archana Shrestha ${ }^{7}$, Bom BC ${ }^{8}$, Sabin 7 Bhandari $^{9}$, Ramgyan Yadav $^{8}$, Ashish Timalsina ${ }^{8}$, Chetan Nidhi Wagle ${ }^{8}$, Brij Kumar Das ${ }^{8}$, 8 Ramesh Kunwar $^{8}$, Binaya Chalise ${ }^{10}$, Deepak Raj Bhatta ${ }^{8}$, and Mukesh Adhikari ${ }^{8,11 \pi}$

1. School of Medicine, Case Western Reserve University, Euclid Ave, Cleveland USA.

2. Central Department of Public Health, Institute of Medicine, Tribhuvan University, Kathmandu, Nepal

3. Department of Social and Behavioral Sciences, Yale School of Public Health, Yale University, New Haven, CT, USA

4. Yale Center for Interdisciplinary Research on AIDS, Yale School of Public Health, New Haven, CT, USA

5. Department of Preventive Medicine, College of Medicine, Dongguk University, South Korea

6. Department of Epidemiology of Microbial Diseases, Yale School of Public Health, Yale University, New Haven CT, USA

7. Department of Public Health, Kathmandu University, Kathmandu, Nepal

8. Ministry of Health and Population, Kathmandu, Nepal

9. B.P Koirala Institute of Health Sciences, Dharan, Nepal

10. Hiroshima University, Graduate School for International Development and Cooperation, Hiroshima, Japan

11. Department of Health Policy and Management, Yale School of Public Health, Yale University, New Haven CT, USA 


\section{Corresponding Author}

35 1. Mr. Dipak Prasad Upadhyaya

40 "II These authors contributed equally to this work.

41

42

43

44

45

46

47

48

49

50

51

52

53

54

55

56

57

58

59

60

61

62

63 


\section{Abstract}

\section{Background}

67 The health sector's effectiveness during a pandemic primarily depends on the availability,

68 knowledge, skills, perceptions, and motivations of frontline healthcare workers. In this study, we

69 aimed to investigate the contextual factors associated with the knowledge, perceptions, and the

70 willingness of frontline healthcare workers to work during the COVID-19 pandemic in Nepal.

\section{Methods}

72 A total of 1051 frontline health-workers from all seven Nepalese provinces were included in this

73 web-based cross-sectional study, which was conducted in May 2020. Using a 5-point Likert

74 scale questionnaire, we collected information on knowledge, perceptions, and the willingness of

75 frontline healthcare workers to work during the COVID-19 pandemic. Multivariable logistic

76 regression was applied to identify independent associations between predictors and outcome

77 variables.

\section{Results}

79 Of the 1051 frontline health-workers, $17.2 \%$ were found to have inadequate knowledge on

80 COVID-19, 63.6\% reported unsatisfactory perceptions of government response, and 35.9\%

81 showed an unwillingness to work during the pandemic. Health workers at local health facilities

82 (AOR: 0.35; 95\% CI: 0.17-0.68) and those with chronic diseases were less likely to have

83 adequate knowledge of COVID-19. Nurses (AOR: 2.10; 95\% CI: 1.38-3.18), health-workers

84 from Karnali Province (AOR: 2.62; 95\% CI: 1.52-4.53), and those who had adequate knowledge

85 of COVID-19 (AOR: 3.86; 95\% CI: 2.51-6.16) were more likely to have satisfactory perception 
medRxiv preprint doi: https://doi.org/10.1101/2020.08.12.20173609; this version posted August 14, 2020. The copyright holder for this preprint (which was not certified by peer review) is the author/funder, who has granted medRxiv a license to display the preprint in perpetuity.

It is made available under a CC-BY 4.0 International license .

86 towards government response to COVID-19. In addition, laboratory-workers, health workers

87 from Karnali province, and those with adequate knowledge (AOR: 1.81; 95\% CI: 1.27-2.58)

88 were more likely to work during the COVID-19 pandemic.

\section{Conclusions}

90 We concluded that frontline healthcare workers have some gaps in knowledge-related to

91 COVID-19; about two-thirds of them had a negative perception of government response, and

92 nearly one-third of them were unwilling to work. These observations demonstrate that prompt

93 actions are required to improve health-worker knowledge of COVID-19, address negative

94 perceptions to government responses, and motivate them to provide healthcare services during

95 the pandemic.

96 Keywords: COVID-19, Health-workers, Knowledge, Perception, Willingness 
medRxiv preprint doi: https://doi.org/10.1101/2020.08.12.20173609; this version posted August 14, 2020. The copyright holder for this preprint (which was not certified by peer review) is the author/funder, who has granted medRxiv a license to display the preprint in perpetuity.

It is made available under a CC-BY 4.0 International license .

\section{Introduction}

111 In December 2019, an outbreak of a pneumonia-like illness was first detected in Wuhan, Hubei

112 Province of China[1], and subsequently, faced with an escalating number beyond China, the

113 World Health Organization (WHO) declared the outbreak a pandemic[2]. Based on available

114 evidence, the disease is transmitted between individuals via nasopharyngeal droplets or saliva.

115 Furthermore, no vaccine or effective treatment for COVID-19 is currently available[3]. Nepal is

116 a small country in South Asia that shares a border with China and observed its first case of

117 COVID-19 on January 25, 2020 [4]. In the first half of May 2020, Nepal experienced an

118 explosive increase in cases; more than three-fourths of all cases recorded do date occurred during

119 this period. As of May 24, 2020, Nepal reported 603 cases and three fatalities [5]. To tackle the

120 COVID-19 pandemic, Nepal first sealed its border with China, and then suspended all

121 international flights and, on March 23, implemented a country-wide comprehensive lock-down.

122 On April 3, after encountering its first case of local transmission, Nepal began to utilize its

123 resources more systematically [6].

124

125 Concern has been expressed that health systems in low-income countries like Nepal are not

126 sufficiently resilient to tackle a crisis like that presented by COVID-19. Due to resource

127 constraints and a weak health system structure, rapid diagnosis of suspected cases and contact

128 tracing are challenging[6]. Studies have shown that knowledge of infectious diseases is greatest

129 among doctors and nurses[7,8]. In addition, age, sex, educational status, and preexisting medical

130 conditions have been shown to affect health worker (HW) knowledge of Middle East Respiratory

131 Syndrome (MERS), and Severe Acute Respiratory Syndrome (SARS)[9,10]. The primary

132 sources of information about COVID 19 are international health organizations such as the Center 
133 for Disease Control (CDC), WHO and Ministry of Health, and social media. Moreover, the

134 effectiveness of healthcare sectors during public health emergencies primarily depends on the

135 availability, motivation and skills of frontline healthcare workers, and thus knowledge, their

136 perceived willingness to work during uncertain times is essential [11], because appropriate

137 perceptions and willingness to work during a pandemic are prerequisites of $\mathrm{HW}$ motivation to

138 provide necessary treatment and to take the preventive actions required to reduce pandemic's

139 impact. Studies have shown that factors such are perceived personal risks, availability of

140 personal protective equipment, family care obligations, HW gender, type of employment,

141 personal confidence, defined role, dissemination of timely information, appropriate training, and

142 personal health problems, influence perceptions and willingness to work during pandemics [11-

143 14]. In the present study, frontline Healthcare Workers were defined as doctors, nurses,

144 paramedics, laboratory workers, pharmacists, pathologist, technical personnel, public health

145 workers, and others directly involved in COVID-19 prevention and treatment that have direct

146 contact with confirmed or suspected cases during patient intake, screening, inspection, testing,

147 transport, treatment, nursing, specimen collection, or pathogen detection.

148 To provide healthcare services effectively, it is essential to assess and update $\mathrm{HW}^{\prime}$ knowledge

149 and improve motivation, and willingness, which depends on various factors at the individual, and

150 to system levels. The present study describes the actual HW scenarios factors associated with

151 their knowledge of COVID-19, their reactions to government interventions, and, most

152 importantly, their perceived willingness to work during the pandemic. This study also provides

153 valuable and actionable information to Nepal's policymakers to allow the judicious allocation of

154 scarce resources in the short run. In the long term, this study guides for those developing policies

155 and programs. That might be instrumental in ensuring preparedness to meet the challenges posed 
medRxiv preprint doi: https://doi.org/10.1101/2020.08.12.20173609; this version posted August 14, 2020. The copyright holder for this preprint (which was not certified by peer review) is the author/funder, who has granted medRxiv a license to display the preprint in perpetuity.

It is made available under a CC-BY 4.0 International license .

156 by similar crises. Given this background, we aimed to investigate the contextual factors

157 associated with the perceptions and willingness to work among Nepalese front-line healthcare

158 workers during the COVID-19 pandemic to improve the prevention and management of future

159 similar outbreaks.

160

161 Methods

\section{Study participants and Sampling}

163 We conducted a cross-sectional study using an online questionnaire from May 2020, among

164 HWs in Nepal in accord with the Checklist for Reporting Results of Internet Surveys

165 (CHERRIES) [15]. All participating HWs were aged 18 to 60 years old and ranged from high-

166 level officials of the Ministry of Health and Population to paramedics working at the grassroots

167 level in all seven provinces on Nepal. The research questionnaire was distributed to HWs using

168 the health workers' network. As an initial step, we first appointed a doctor or public health

169 professional in each of the seven provinces to act as a coordinator and co-investigator in the

170 team. These seven coordinators then sent HWs known to them a link to our questionnaire and

171 asked that these individuals send a Google link to other HWs they knew. Fischer's arctanh

172 transformation as a power of $90 \%$ and a minimum correlation of $0.1[16]$, showed that the

173 minimum sample size required was $n=1046$.

\section{Survey Instrument and data collection}


medRxiv preprint doi: https://doi.org/10.1101/2020.08.12.20173609; this version posted August 14, 2020. The copyright holder for this preprint (which was not certified by peer review) is the author/funder, who has granted medRxiv a license to display the preprint in perpetuity.

It is made available under a CC-BY 4.0 International license .

175 The online questionnaire included 33 questions on socioeconomic characteristics, HWs'

176 knowledge of COVID-19, perception toward government response toCOVID-19, and perceived

177 willingness to work during the pandemic. The Responses were rated using a 5-point Likert Scale

178 ("Strongly Agree," "Agree," "Neutral," "Disagree" to "Strongly Disagree").

179

180 The socio-demographic characteristics investigated included age, gender, ethnicity, and marital

181 status. This section of the questionnaire also included questions about chronic diseases of HWs,

182 their caretaking responsibilities for dependent family members, nature of the employment, and

183 type of health facility at which they worked. Knowledge of COVID-19 was rated as "adequate"

184 and "inadequate," perception of government response as "satisfactory" and "unsatisfactory" and

185 willingness to work as "willing" and "unwilling." Knowledge of COVID-19 was assessed based

186 on knowledge of the causative agent, mode of transmission, proper use of PPE, infection

187 prevention measures, and public health impact of the pandemic. Reaction to government

188 response was determined by assessing response effectiveness, timeliness of information

189 provided, provision of supplies, support received from administrative staff, and elected

190 representatives. Factors influencing willingness to work during the pandemic were risk of self

191 infection, healthcare service rationing, the requirement to work overtime, working with untrained

192 HWs, deployment to another duty station, family risk, and ability to choose whether to work or

193 not during the pandemic.

195 The questionnaire was prepared based on national COVID-19 guidelines issued by the Ministry

196 of Health and Population of Nepal[17] and World Health Organization resource center guidelines

197 for HWs on COVID-19 [18]. A team of medical doctors, public health workers, and an academic 
medRxiv preprint doi: https://doi.org/10.1101/2020.08.12.20173609; this version posted August 14, 2020. The copyright holder for this preprint (which was not certified by peer review) is the author/funder, who has granted medRxiv a license to display the preprint in perpetuity.

It is made available under a CC-BY 4.0 International license .

assessed the questionnaire for validity and relevance. Before conducting the survey, we conducted a pilot study on 30 participants to assess the reliability of the questionnaire items. The analysis revealed an overall Cronbach's alpha score of 0.77 , indicating higher internal consistency[19]. The questionnaire was prepared as a Google Form, and Facebook Messenger was used to sending the Google form link to participants [20,21]. The questionnaire took approximately 10 minutes to complete. To maintain data confidentiality, only two research team members had access to the data repository, stored on a password-protected computer.

\section{Data Management and Statistical Analysis}

207 The data collected was downloaded in the form of a spreadsheet and checked for duplications

208 and technical errors. After confirming the completeness, we exported the data to R Studio

209 Software for full analysis [22]. Socio-demographic characteristics were subjected to descriptive

210 analysis using the table 1package in $\mathrm{R}$ software, and results are presented as frequencies,

211 percentages, or as means and standard deviations [23].

213 Univariate logistic regression analysis was used to assess factors associated with adequate

214 knowledge, satisfaction with the government response, and willingness to work using

215 the finalfit package in R [24]. Parsimonious multivariate models were created for each dependent 216 variable and included independent variables found to be significant ( $\mathrm{p}$-value <0.05) by univariate

217 analysis. Coefficients in the regression models were transformed into odds ratios with $95 \%$

218 confidence intervals. P-values of $<0.05$ were considered significant. 


\section{Ethics statement}

222 Ethical approval for the study was obtained from the Nepal Health Research Council (approval

223 no: 329/2020 P). The first page of the questionnaire detailed the study objective, benefits, and

224 harm. HWs provided e-consent prior to participating in the study. Participants were informed

225 that they could leave the study at any time. Participation was voluntary and anonymous.

226

227 Results

\section{Socio-demographic characteristics}

229 A total of $1051 \mathrm{HWs}$ participated in the study, $725(68 \%)$ men and $326(31 \%)$ women. The

230 response rate was $79 \%$. Table 1 shows the socio-demographic characteristics of health care

231 workers who participated in the study. Nearly $49 \%$ of the participants were aged between 20 to

23230 years. More than half (57.4\%) of the HWs were Brahmin or Chhetri. The majority of the

233 participants were doctors $(35.3 \%)$ and nurses or midwives (16.5\%). Highest percentage response

234 was from Bagmati Province (19.4\%), which contains the capital city Kathmandu. Detailed

235 information about the provinces of Nepal is explained in Additional File. Nearly $60 \%$ of HWs

236 were permanent employees. More than 25\% worked in local-level public health facilities, such as

237 health posts, primary health care centers, community health units, and urban health centers. More

238 than $50 \%$ worked in hospitals, public hospitals $(22.8 \%)$ followed by teaching hospitals and

239 private hospitals. Nearly $20 \%$ of respondents used a health-related managerial agency at the 
medRxiv preprint doi: https://doi.org/10.1101/2020.08.12.20173609; this version posted August 14, 2020. The copyright holder for this preprint (which was not certified by peer review) is the author/funder, who has granted medRxiv a license to display the preprint in perpetuity.

It is made available under a CC-BY 4.0 International license.

240 federal, provincial, or local levels. 13.5\% of HWs reported having a chronic disease; the most

241 common of which were diabetes, heart disease, and chronic respiratory disease and 64\% of HWs

242 had family members of less than five years or more than 60 years who needed their care and

243 support. [Please insert Table 1 here].

244

245 Health Worker' Knowledge of COVID-19

246 More than $80 \%$ of HWs had adequate knowledge of COVID-19 (See Table 2), and the

247 percentage of men with adequate knowledge was higher than that of women. No significant

248 difference in knowledge was observed among ethnic groups. However, significant differences

249 were observed among health professionals. More than $90 \%$ of public health workers had

250 adequate knowledge, while only $61.5 \%$ of other health workers such as Ayurveda—an ancient

251 medical system prevalent in Nepal [25] and pharmacists had adequate knowledge. No provincial

252 differences in COVID-19 knowledge were observed. However, knowledge of COVID-10

253 differed among HWs employed at different health facility types. No difference in COVID-19

254 related knowledge was found between those with or without chronic diseases or caretaking

255 responsibilities. Multivariate logistic regression analysis showed that gender, professional

256 category, and type of healthcare facility were associated with adequate knowledge of COVID-19,

257 as shown in Table 2. Males were more likely to have adequate knowledge (OR: 1.60; $95 \%$ CI:

258 1.02-2.47) than females. HWs in“other” professional categories such as pharmacists, and

259 Ayurveda—had less adequate knowledge than doctors (OR: 0.33; $95 \%$ CI: 0.14-0.80). HWs

260 working at local health facilities were more likely to have inadequate knowledge about COVID- 
medRxiv preprint doi: https://doi.org/10.1101/2020.08.12.20173609; this version posted August 14, 2020. The copyright holder for this preprint (which was not certified by peer review) is the author/funder, who has granted medRxiv a license to display the preprint in perpetuity.

It is made available under a CC-BY 4.0 International license .

26119 than those working at federal or provincial agencies (OR: 0.35; $95 \%$ CI 0.17-0.68). [Please 262 insert Table 2 here].

264 Health Workers' reactions to government response to COVID-19

265 Pandemic

266 More than $60 \%$ of HWs considered government response to COVID-19 Pandemic was

267 unsatisfactory (Table 3). Gender and ethnicity were not found to influence perceptions of

268 government response significantly. Nearly $74 \%$ of doctors reported government response to be

269 unsatisfactory, while only $43 \%$ of public health workers thought so. About $72 \%$ of HWs from

270 Bagmati Province and Province 2 were dissatisfied with the government response. Chronic

271 disease and caretaking responsibility did not influence reactions to government response.

272

273 Multivariate logistic regression showed the reactions of HWs to government response were

274 associated with a professional category, province, type of health facility, and adequacy of

275 knowledge about COVID-19 (Table 3). Nurses were more likely to consider government

276 response satisfactory than doctors (OR: 2.10; $95 \%$ CI: 1.38-3.18). Similarly, public health

277 professionals were more likely to consider government response to COVID-19 was satisfactory

278 than doctors (OR: 1.83; CI 1.07 - 3.11). HWs from Province 6 (OR:2.62; $95 \%$ CI: 1.52-4.53)

279 and Province 7 (OR: 1.72; CI: 1.06-2.80) were more likely to consider government response

280 satisfactory than those from Bagmati Province. Those working in public and teaching hospitals

281 and local public health facilities were less likely to consider government response satisfactory

282 than HW working from federal and provincial-level agencies. Interestingly, HWs with adequate 
medRxiv preprint doi: https://doi.org/10.1101/2020.08.12.20173609; this version posted August 14, 2020. The copyright holder for this preprint (which was not certified by peer review) is the author/funder, who has granted medRxiv a license to display the preprint in perpetuity.

It is made available under a CC-BY 4.0 International license .

283 knowledge of COVID-19 were more likely to consider government response satisfactory (OR:

284 3.86; $95 \%$ CI 2.51-6.16) [Please insert Table 3 here].

285

286 Health workers' willingness to work during the COVID-19

287 Pandemic

288 About $64 \%$ of HWs reported a willingness to work under the challenging conditions created

289 during the COVID-19 Pandemic (Table 4). No significant difference was observed between men

290 and women with respect to willingness to work. About $74 \%$ of laboratory workers were willing

291 to work whereas, only $48.5 \%$ of doctors were willing to do so. Furthermore, differences were

292 observed between the seven provinces; $\simeq 85 \%$ of HWs in Karnali Province, but only $54.5 \%$ of

293 HWs from Province 2 were willing to work.

294

295 Multivariate analysis showed a willingness to work was associated with the professional

296 category, province, presence of chronic disease, caregiving responsibility, and knowledge of

297 COVID-19. Laboratory staffs (OR: 3.54; 95 \% CI: 1.77-7.61), paramedics (OR: 2.52; 95 \% CI:

298 1.79 - 3.58), public health workers (OR: 2.40; $95 \%$ CI: 1.47-4.01), and nurses/midwives (OR:

$2992.09 ; 95 \%$ CI: 1.40-3.47), were more willing to work during the pandemic than doctors. HWs

300 from Karnali Province (OR: 2.96; 95 \% CI: 1.62-5.64), and Sudurpaschim Province (OR: 2.10;

$30195 \%$ CI: 1.28-3.48) were more likely to report willingness to work than those from Bagmati

302 Province. HWs with responsibility for dependent family members were less willing to work than

303 those without these responsibilities (OR: 0.72; 0.54-0.95). Finally, the HWs with adequate 
medRxiv preprint doi: https://doi.org/10.1101/2020.08.12.20173609; this version posted August 14, 2020. The copyright holder for this preprint (which was not certified by peer review) is the author/funder, who has granted medRxiv a license to display the preprint in perpetuity.

It is made available under a CC-BY 4.0 International license .

304 knowledge of COVID-19 were more prepared to work than those with inadequate knowledge

305 (OR: 1.81; 1.27- 2.55). [Please insert Table 4 here]

306

307 Discussion

308 This is the first nationwide study on knowledge and perception of COVID-19 among frontline

309 healthcare workers and their willingness to work during the pandemic in Nepal. About two in ten

310 frontline healthcare workers (17.2\%) had inadequate knowledge of COVID-19, which is higher

311 than that reported in a Chinese study, in which $\simeq 11 \%$ demonstrated insufficient knowledge[26].

312 On the other hand, a study conducted by Bhagavathula S.A et al. reported that $61 \%$ of health

313 workers had poor knowledge about COVID-19 transmission [27]. These differences between

314 rates may have been due to variations in the level of knowledge accessed. Furthermore, the latter

315 study was conducted in the first week of March 2020, and the Chinese study was conducted in

316 the third week of May, when more information regarding COVID 19 was available and

317 disseminated through different media. Knowledge is crucial for establishing perception and

318 preventive behavior, which both affect coping interventions to some degree [28].

319 In addition, we found nearly two-thirds healthcare works (63.6\%) believed government response

320 to COVID-19 was unsatisfactory. A slightly higher level of satisfaction with government

321 response was reported in a survey conducted on the Nepalese general public in April 2020 (71.4

$322 \%)$ [29]. The present stud also showed that most HWs (86\%) experienced logistical shortcomings

323 and reported inadequate supports form administrative (60\%) and elected representatives (67.5\%),

324 which concurs with findings of a previous study[30]. Furthermore, our study shows that more

325 than one in three HW (35.8\%) were unwilling to work during the pandemic, which is 
326 considerable issues because the health system's workload during the pandemic will be so high

327 that all available health resources will be required to combat emergencies. In addition, the rate

328 observed were higher than those reported in several other studies on willingness to work among

329 health workers during public health emergencies[12-14,31,32]. In the present study, these high

330 rates may have been due to inadequate knowledge (17\%), preexisting chronic disease (13.5\%),

331 shortage of PPE (86\%) and other factors [32,33]. The high rates of unwillingness to work during

332 the pandemic revealed by our study demand the additional efforts be made to rectify the

333 situation.

334 We also found that male health workers were more likely to report adequate knowledge; which is 335 consistent with that found in another study conducted in Nepalese [34]. This finding may be due 336 to greater interaction and socialization by men, and gendered norms, which means men are more 337 likely to overestimate, and women are likely to underestimate personal knowledge [35-38]. The 338 study also showed that pharmacists and Ayurveda had inadequate knowledge of COVID-19 rates 339 as compared with doctors; finding is similar to a survey conducted in Nepal [34]. We also found 340 that HWs in the local health facilities were less likely to have adequate knowledge than the HWs 341 in federal or provincial agencies, which was possibly due to weaker implementation of COVID-

34219 related governmental interventions at the local level than that at provincial or federal levels.

343 In addition, HWs with a chronic disease considered they had inadequate knowledge of COVID-

344 19, perhaps because time limitations imposed by pre-existing conditions restricted studies about 345 COVID-19.

346 This study shows that the professional category, province, type of health facility, and knowledge

347 of COVID-19 were significantly associated with frontline health workers' satisfaction with 
medRxiv preprint doi: https://doi.org/10.1101/2020.08.12.20173609; this version posted August 14, 2020. The copyright holder for this preprint (which was not certified by peer review) is the author/funder, who has granted medRxiv a license to display the preprint in perpetuity.

It is made available under a CC-BY 4.0 International license .

government response to the pandemic. Nurses were found to be more likely to be satisfied with government response than counterpart frontline doctors. This perception difference might have been due to the differences between levels of technical knowledge among doctors, nurses, and

351 public health workers. Furthermore, health workers from Karnali and Sudurpaschim Provinces

352 were more likely to be satisfied with government response than HWs from Bagmati province.

353 However, the reasons responsible for these provincial variations were not determined. In

354 addition, HWs from local public health facilities, teaching hospitals, and private hospitals had unsatisfactory perceptions than managerial level HWs at the ministry level, which we attribute to

356 different work experiences, as HWs at health service outlets are directly exposed to risks and

357 better understand the risks posed by logistical shortfalls than managerial level HWs.

358 Interestingly, HWs with adequate knowledge of COVID-19 were more satisfied with 359 government response than HWs with inadequate knowledge.

360 Interestingly, health workers professional category, province, presence of chronic disease, 361 dependent family members, and knowledge about COVID 19 were associated with a willingness

362 to work during the pandemic, and nurses, paramedics, public health workers, and laboratory staff

363 were more willing to work than clinicians, which contradicts the results of a systematic review

364 conducted by Aoyagi et al. [39]. HWs from Karnali and Sudurpaschim provinces were more

365 willing to work than counterparts from Bagmati province. Similarly, it might be possible that due

366 to virtually no cases of COVID-19 during the study, the HWs were willing to work in a humane

367 way. Furthermore, HWs with adequate knowledge about COVID-19 were more willing to work,

368 which concurs with a study performed on the 2007 influenza pandemic [40]. Our result shows

369 that HWs with a chronic disease[41] and those that cared for family members[40] were less

370 willing to work, which is also in line with previous studies [12,39]. It may be caring for family 
medRxiv preprint doi: https://doi.org/10.1101/2020.08.12.20173609; this version posted August 14, 2020. The copyright holder for this preprint (which was not certified by peer review) is the author/funder, who has granted medRxiv a license to display the preprint in perpetuity.

It is made available under a CC-BY 4.0 International license .

371 members and that coping with personal chronic health problems diminishes willingness to work

$372[41]$.

373 This study was conducted to identify predictors of the willingness of frontline healthcare workers

374 to work during the COVID-19 pandemic. The findings of this study can be used to inform

375 various stakeholders and policymakers involved in the drafting of future interventions to improve

376 the effectiveness of the health sector during public health crises. However, despite our efforts,

377 this study has several limitations. First, data was obtained using a questionnaire over the web and

378 health care workers were recruited using their personal networks. Therefore, our results should

379 not be extended to healthcare workers that do not use the internet. Second, the data used was

380 self-reported, which makes the study prone to desirability bias and inaccuracies. Furthermore,

381 participants were asked to consider their willingness to work under hypothetical conditions that

382 did not exist when Nepal comparatively observed a lower number of cases and fatalities. We

383 recommend studies of the impacts of HW knowledge, perception, and willingness to work on

384 health sector efficiency in the context of public health emergencies be undertaken.

\section{Conclusions}

387 Health workers play an extremely critical role in the battle against pandemics. Therefore, their

388 knowledge about the disease and their willingness to work are crucially required to prevent

389 disease transmission and reduce morbidity and mortality. In view of the perceived knowledge

390 gap of health workers about COVID-19, adequate training provides a means of addressing this

391 shortcoming. The high-level dissatisfaction of HWs with logistical issues and shortages should

392 also be at the focus of efforts to improving perceptions of government response. Health 
medRxiv preprint doi: https://doi.org/10.1101/2020.08.12.20173609; this version posted August 14, 2020. The copyright holder for this preprint (which was not certified by peer review) is the author/funder, who has granted medRxiv a license to display the preprint in perpetuity.

It is made available under a CC-BY 4.0 International license .

393 managers should be fully aware of the impacts of factors and devise comprehensive approaches

394 that ensure the safety of HWs and promote coordination to motivate the HWs to work efficiently

395 and effectively in a sustainable manner throughout the COVID-19 pandemic.

396

397 List of Abbreviations:

398

399 COVID-19: $\quad$ Coronavirus Disease 2019

$400 \quad$ CI: Confidence Interval

401 HWs: $\quad$ Health Workers

402 MoHP: $\quad$ Ministry of Health and Population

403 OR: Odds Ratio

404 SARS-CoV-2: $\quad$ Severe Acute Respiratory Syndrome, Coronavirus 2

405 WHO: $\quad$ World Health Organization

406

407 Declarations:

408

409 Ethics approval and consent to participate:

410

411 The study protocol was approved by the Institutional Review Board of the Nepal Health

412 Research Council (ERB Protocol Registration No. 329/2020 P). Electronic consent was required 
medRxiv preprint doi: https://doi.org/10.1101/2020.08.12.20173609; this version posted August 14, 2020. The copyright holder for this preprint (which was not certified by peer review) is the author/funder, who has granted medRxiv a license to display the preprint in perpetuity.

It is made available under a CC-BY 4.0 International license .

413 from all participants prior to completing the online questionnaire. A detailed description of the

414 study was supplied on the first page of the online questionnaire.

415

416 Consent for publication:

417 Not applicable.

418

419 Competing Interests

420 The authors have no conflict of interest to declare.

421

422 Availability of data and materials:

423 Data will be made available upon reasonable request by email to the corresponding author.

424

425 Author Contributions

426 DPU, RP and MA conceptualized the study. DPU, RP, MA, AT, BC, and BB developed and

427 pretested the questionnaire. BB, SB, RGY, RK, CNW, BKD, AT, MA, DRB, DPU, and RP 428 supported data collection. DPU, MA, DJB, and RP performed the statistical analysis. DPU, MA 429 and RP wrote the manuscript, and, DJB, KK, RP, KL, AS, JHP, SJY and DA edited, revised and 430 finalized the manuscript. All authors contributed to the writing, editing, revision, and critical 431 appraisal of the manuscript. All authors read and approved the final version of the manuscript. 
medRxiv preprint doi: https://doi.org/10.1101/2020.08.12.20173609; this version posted August 14, 2020. The copyright holder for this preprint (which was not certified by peer review) is the author/funder, who has granted medRxiv a license to display the preprint in perpetuity.

It is made available under a CC-BY 4.0 International license .

\section{Acknowledgments:}

434 We authors thank Seema Subedi, a researcher at John Hopkins University, USA, for her

435 suggestions during the conceptualization of the study. We wish to express our appreciation to all

436 health workers that participated in the study. More importantly, we salute them for their tireless

437 efforts to provide health services during the unprecedented challenge posed by COVID-19.

\section{Author Information:}

440 DPU is a graduate student at the School of Medicine, Case Western Reserve University, Euclid

441 Ave, Cleveland USA, and faculty at Central Department of Public Health, Institute of Medicine,

442 Tribhuvan University, Nepal. RP is an Assistant Professor at the Central Department of Public

443 Health, Institute of Medicine, Tribhuvan University, Nepal. MA is an employee of the Ministry

444 of Health and Population, and a graduate student at the Yale School of Public Health, Yale

445 University, USA. DJB is a graduate student at the Yale School of Public Health, Yale University.

$446 \mathrm{KK}$ is an associate professor at Yale School of Public Health, AS is an associate professor at the

447 Department of Public Health, Kathmandu University, Nepal. AT, BB, RGY, CNW, BKD, RK,

448 and DRB are employed by the Ministry of Health and Population, Government of Nepal. SB is

449 an assistant professor at B.P Koirala Institute of Health Sciences, Dharan, Nepal. BC is a student

450 at a Graduate School for International Development and Cooperation, Hiroshima University,

451 Japan. KL, JHP, and SJY are professors at the Department of Preventive Medicine, College of

452 Medicine, Dongguk University, Gyeongju, South Korea. DA is a recent doctoral graduate from

453 the Department of Preventive Medicine, College of Medicine, Dongguk University, South

454 Korea. All authors have read and understood the ICMJE criteria for authorship policy. 


\section{References}

1. Huang C, Wang Y, Li X, Ren L, Zhao J, Hu Y, et al. Clinical features of patients infected with 2019 novel coronavirus in Wuhan, China. The Lancet. 2020;395: 497-506. doi:10.1016/S0140-6736(20)30183-5

2. WHO Director-General's opening remarks at the media briefing on COVID-19 - 11 March 2020. [cited 4 Jun 2020]. Available: https://www.who.int/dg/speeches/detail/who-directorgeneral-s-opening-remarks-at-the-media-briefing-on-covid-19---11-march-2020

3. Coronavirus. [cited 10 Jul 2020]. Available: https://www.who.int/westernpacific/healthtopics/coronavirus

4. Shrestha R, Shrestha S, Khanal P, Kc B. Nepal's first case of COVID-19 and public health response. J Travel Med. 2020;27. doi:10.1093/jtm/taaa024

5. Corona Info- Ministry of Health and Population. [cited 10 Jul 2020]. Available: https://covid19.mohp.gov.np/\#/

6. health-sector-emergency-response-plan-covid-19-endorsed-may-2020.pdf. Available:

7. Huynh G, Nguyen TNH, Tran VK, Vo KN, Vo VT, Pham LA. Knowledge and attitude https://www.who.int/docs/default-source/nepal-documents/novel-coronavirus/health-sectoremergency-response-plan-covid-19-endorsed-may-2020.pdf?sfvrsn=ef831f44_2 toward COVID-19 among healthcare workers at District 2 Hospital, Ho Chi Minh City. Asian Pac J Trop Med. 2020;13: 260. doi:10.4103/1995-7645.280396

8. Olum R, Chekwech G, Wekha G, Nassozi DR, Bongomin F. Coronavirus Disease-2019: Knowledge, Attitude, and Practices of Health Care Workers at Makerere University Teaching Hospitals, Uganda. Front Public Health. 2020;8. doi:10.3389/fpubh.2020.00181

9. Khan MU, Shah S, Ahmad A, Fatokun O. Knowledge and attitude of healthcare workers about middle east respiratory syndrome in multispecialty hospitals of Qassim, Saudi Arabia. BMC Public Health. 2014;14: 1281. doi:10.1186/1471-2458-14-1281

10. Deng J-F, Olowokure B, Kaydos-Daniels SC, Chang H-J, Barwick RS, Lee M-L, et al. Severe acute respiratory syndrome (SARS): knowledge, attitudes, practices and sources of information among physicians answering a SARS fever hotline service. Public Health. 2006;120: 15-19. doi:10.1016/j.puhe.2005.10.001

11. Watt K, Tippett VC, Raven SG, Jamrozik K, Coory M, Archer F, et al. Attitudes to living and working in pandemic conditions among emergency prehospital medical care personnel. Prehospital Disaster Med. 2010;25: 13-19. doi:10.1017/s1049023x00007597

12. Martin SD. Nurses' ability and willingness to work during pandemic flu. J Nurs Manag. 2011;19: 98-108. doi:10.1111/j.1365-2834.2010.01190.x 
medRxiv preprint doi: https://doi.org/10.1101/2020.08.12.20173609; this version posted August 14, 2020. The copyright holder for this preprint (which was not certified by peer review) is the author/funder, who has granted medRxiv a license to display the preprint in perpetuity.

It is made available under a CC-BY 4.0 International license.

13. Hope K, Durrheim D, Barnett D, D'Este C, Kewley C, Dalton C, et al. Willingness of frontline health care workers to work during a public health emergency. Aust J Emerg Manag. 2010;25: 39-47.

14. Qureshi K, Gershon RRM, Sherman MF, Straub T, Gebbie E, McCollum M, et al. Health care workers' ability and willingness to report to duty during catastrophic disasters. J Urban Health Bull N Y Acad Med. 2005;82: 378-388. doi:10.1093/jurban/jti086

15. Eysenbach G. Improving the Quality of Web Surveys: The Checklist for Reporting Results of Internet E-Surveys (CHERRIES). J Med Internet Res. 2004;6: e34. doi:10.2196/jmir.6.3.e34

16. Computational Statistics with R, Volume 32 - 1st Edition. [cited 10 Jul 2020]. Available: https://www.elsevier.com/books/computational-statistics-with-r/rao/978-0-444-63431-3

17. Coronavirus disease (COVID-19) outbreak updates \& resource materials - Health Emergency Operation Center. [cited 10 Jul 2020]. Available: https://heoc.mohp.gov.np/update-on-novel-corona-virus-covid-19/

18. Technical guidance publications. [cited 10 Jul 2020]. Available: https://www.who.int/emergencies/diseases/novel-coronavirus-2019/technical-guidancepublications

19. Using and Interpreting Cronbach's Alpha | University of Virginia Library Research Data Services + Sciences. [cited 10 Jul 2020]. Available: https://data.library.virginia.edu/usingand-interpreting-cronbachs-alpha/

20. Google Forms. [cited 10 Jul 2020]. Available: https://docs.google.com/forms/u/0/?usp=mkt_forms

21. Social Media Stats Nepal. In: StatCounter Global Stats [Internet]. [cited 10 Jul 2020]. Available: https://gs.statcounter.com/social-media-stats/all/nepal

22. R: The R Project for Statistical Computing. [cited 10 Jul 2020]. Available: https://www.rproject.org/

23. Using the table1 Package to Create HTML Tables of Descriptive Statistics. [cited 10 Jul 2020]. Available: https://cran.r-project.org/web/packages/table1/vignettes/table1examples.html

24. Harrison E, Drake T, Ots R. finalfit: Quickly Create Elegant Regression Results Tables and Plots when Modelling. 2020. Available: https://CRAN.R-project.org/package=finalfit

25. Durkin M. Ayurvedic treatment for jaundice in Nepal. Soc Sci Med. 1988;27: 491-495. doi:10.1016/0277-9536(88)90372-3 
medRxiv preprint doi: https://doi.org/10.1101/2020.08.12.20173609; this version posted August 14, 2020. The copyright holder for this preprint (which was not certified by peer review) is the author/funder, who has granted medRxiv a license to display the preprint in perpetuity.

It is made available under a CC-BY 4.0 International license.

26. Zhang M, Zhou M, Tang F, Wang Y, Nie H, Zhang L, et al. Knowledge, attitude, and practice regarding COVID-19 among healthcare workers in Henan, China. J Hosp Infect. 2020;105: 183-187. doi:10.1016/j.jhin.2020.04.012

27. Bhagavathula AS, Aldhaleei WA, Rahmani J, Mahabadi MA, Bandari DK. Knowledge and Perceptions of COVID-19 Among Health Care Workers: Cross-Sectional Study. JMIR Public Health Surveill. 2020;6: e19160. doi:10.2196/19160

28. McEachan R, Taylor N, Harrison R, Lawton R, Gardner P, Conner M. Meta-Analysis of the Reasoned Action Approach (RAA) to Understanding Health Behaviors. Ann Behav Med Publ Soc Behav Med. 2016;50: 592-612. doi:10.1007/s12160-016-9798-4

29. COVID 19, Citizen's pulse (A National Survey on COVID 19-Nepal) - Participedia. [cited $10 \mathrm{Jul}$ 2020]. Available: https://participedia.net/case/6543

30. Sim MR. The COVID-19 pandemic: major risks to healthcare and other workers on the front line. Occup Environ Med. 2020;77: 281-282. doi:10.1136/oemed-2020-106567

31. Kaiser HE, Barnett DJ, Hsu EB, Kirsch TD, James JJ, Subbarao I. Perspectives of future physicians on disaster medicine and public health preparedness: challenges of building a capable and sustainable auxiliary medical workforce. Disaster Med Public Health Prep. 2009;3: 210-216. doi:10.1097/DMP.0b013e3181aa242a

32. Balicer RD, Barnett DJ, Thompson CB, Hsu EB, Catlett CL, Watson CM, et al. Characterizing hospital workers' willingness to report to duty in an influenza pandemic through threat- and efficacy-based assessment. BMC Public Health. 2010;10: 436. doi:10.1186/1471-2458-10-436

33. Yonge O, Rosychuk RJ, Bailey TM, Lake R, Marrie TJ. Willingness of university nursing students to volunteer during a pandemic. Public Health Nurs Boston Mass. 2010;27: 174180. doi:10.1111/j.1525-1446.2010.00839.x

34. Knowledge, attitude and practice regarding COVID-19 among healthcare workers in Chitwan, Nepal. 2020 [cited 15 Jul 2020]. doi:10.21203/rs.3.rs-26774/v1

35. Cooper KM, Krieg A, Brownell SE. Who perceives they are smarter? Exploring the influence of student characteristics on student academic self-concept in physiology. Adv Physiol Educ. 2018;42: 200-208. doi:10.1152/advan.00085.2017

36. Ehrlinger J, Dunning D. How chronic self-views influence (and potentially mislead) estimates of performance. J Pers Soc Psychol. 2003;84: 5-17. doi:10.1037/00223514.84.1.5

37. Beyer S. Gender differences in the accuracy of self-evaluations of performance. J Pers Soc Psychol. 1990;59: 960-970. doi:10.1037/0022-3514.59.5.960 
medRxiv preprint doi: https://doi.org/10.1101/2020.08.12.20173609; this version posted August 14, 2020. The copyright holder for this preprint (which was not certified by peer review) is the author/funder, who has granted medRxiv a license to display the preprint in perpetuity.

It is made available under a CC-BY 4.0 International license .

38. Female Medical Students Underestimate Their Abilities And Males Tend To Overestimate Theirs. In: ScienceDaily [Internet]. [cited 10 Jul 2020]. Available: https://www.sciencedaily.com/releases/2008/10/081003122713.htm

39. Aoyagi Y, Beck CR, Dingwall R, Nguyen-Van-Tam JS. Healthcare workers' willingness to work during an influenza pandemic: a systematic review and meta-analysis. Influenza Other Respir Viruses. 2015;9: 120-130. doi:10.1111/irv.12310

40. Daugherty EL, Perl TM, Rubinson L, Bilderback A, Rand CS. Survey study of the knowledge, attitudes, and expected behaviors of critical care clinicians regarding an influenza pandemic. Infect Control Hosp Epidemiol. 2009;30: 1143-1149. doi:10.1086/648085

41. (PDF) Factors Related to Essential Workers' Ability and Willingness to Work and Comply with Personal Infection Control Protocol During a Large Scale Influenza Pandemic in Hawaii. [cited 16 Jul 2020]. Available: https://www.researchgate.net/publication/256456823_Factors_Related_to_Essential_Worke rs'_Ability_and_Willingness_to_Work_and_Comply_with_Personal_Infection_Control_Pr otocol_During_a_Large_Scale_Influenza_Pandemic_in_Hawaii 
Tables

592 Table 1 Sociodemographic Characteristics of Health workers in Nepal

Socio-demographic Characteristics

Age, in years, Median (IQR)

\section{Gender}

Female

Male

\section{Ethnicity}

Brahmin/Chhetri

Madhesi/Muslim

Janajati

Dalit

Other

\section{Frequency (\%) \\ $(n=1051)$}

$31.0(8)$

$326(31.0)$

725 (68.0)

603 (57.4)

209 (19.9)

174 (16.6)

34 (3.2)

31 (2.9)

677 (64.4)

374 (35.6)

371 (35.3)

308 (29.3)

173 (16.5)

122 (11.6)

51 (4.9)

$26(2.5)$

193 (18.4)

156 (14.8)

204 (19.4)

69 (6.6)

153 (14.6)

111 (10.6)

165 (15.7)

613 (58.3)

438 (41.7)

\section{Types of Health Facility}

Federal and Provincial managerial agencies $\varnothing$

134 (12.7) 


\section{Socio-demographic Characteristics}

Teaching Hospital

Public Hospital

Private Hospital

Local public health facilities§

Local-level managerial agencies $\otimes$

Presence of Chronic Disease

No

Yes

\section{Frequency $(\%)$}

$(\mathrm{n}=1051)$

191 (18.2)

$240(22.8)$

132 (12.6)

$292(27.8)$

$62(5.9)$

$909(86.5)$

$142(13.5)$

HWs with care-taking responsibility for children less than 5 years or elderly more than 60 years

No

Yes $670(63.7)$

${ }^{\omega}$ Details about the provinces of Nepal are explained in Additional File 3.

${ }^{\varnothing}$ Consists of the Ministry of Health and Population, the Department of Health Services, the Ministry of Social Development at the province level, Provincial health directorate, and health offices. level.

$\otimes$ Consists of metropolitan, sub-metropolitan, municipalities, and rural municipalities 
Table 2 Factors Associated with Knowledge of COVID-19

\begin{tabular}{|c|c|c|c|c|}
\hline Knowledge about COVID-19 & $\begin{array}{c}\text { Inadequate } \\
\text { Knowledge } \\
(n=181)\end{array}$ & $\begin{array}{c}\text { Adequate } \\
\text { Knowledge } \\
(n=870)\end{array}$ & $\begin{array}{l}\text { OR (univariable) } \\
\text { (95\% CI; p-value) }\end{array}$ & $\begin{array}{l}\text { OR (multivariable) } \\
(95 \% \mathrm{CI} ; \text { p-value }) \phi\end{array}$ \\
\hline \multicolumn{5}{|l|}{ Gender } \\
\hline Female & $72(22.1)$ & 254 (77.9) & - & - \\
\hline Male & $109(15.0)$ & $616(85.0)$ & $1.60(1.15-2.23, \mathrm{p}=0.005) * *$ & $1.60(1.02-2.47, \mathrm{p}=0.036) *$ \\
\hline \multicolumn{5}{|l|}{ Professional Category } \\
\hline Doctor & $60(16.2)$ & $311(83.8)$ & - & - \\
\hline Paramedics & $57(18.5)$ & $251(81.5)$ & $0.85(0.57-1.27, \mathrm{p}=0.423)$ & $1.06(0.65-1.75, \mathrm{p}=0.809)$ \\
\hline Nurse/Midwife & $35(20.2)$ & $138(79.8)$ & $0.76(0.48-1.22, \mathrm{p}=0.246)$ & $1.21(0.67-2.18, \mathrm{p}=0.537)$ \\
\hline Public Health Workers & $11(9.0)$ & $111(91.0)$ & $1.95(1.02-4.03, \mathrm{p}=0.054)$ & $1.65(0.78-3.72, \mathrm{p}=0.203)$ \\
\hline Lab Worker & $8(15.7)$ & $43(84.3)$ & $1.04(0.49-2.48, \mathrm{p}=0.929)$ & $0.92(0.42-2.26, \mathrm{p}=0.851)$ \\
\hline Other & $10(38.5)$ & $16(61.5)$ & $0.31(0.14-0.73, \mathrm{p}=0.006) * *$ & $0.33(0.14-0.80, \mathrm{p}=0.012) *$ \\
\hline \multicolumn{5}{|l|}{ Type of Health Facility } \\
\hline $\begin{array}{l}\text { Federal and Provincial managerial } \\
\text { agencies }\end{array}$ & $12(9.0)$ & $122(91.0)$ & - & - \\
\hline Teaching Hospital & $38(19.9)$ & $153(80.1)$ & $0.40(0.19-0.77, \mathrm{p}=0.009) * *$ & $0.51(0.23-1.09, \mathrm{p}=0.090)$ \\
\hline Public Hospital & $38(15.8)$ & $202(84.2)$ & $0.52(0.25-1.01, \mathrm{p}=0.064)$ & $0.66(0.30-1.37, \mathrm{p}=0.284)$ \\
\hline Private Hospital & $15(11.4)$ & $117(88.6)$ & $0.77(0.34-1.70, p=0.516)$ & $0.95(0.40-2.24, \mathrm{p}=0.915)$ \\
\hline Local public health facilities & $72(24.7)$ & $220(75.3)$ & $0.30(0.15-0.56, \mathrm{p}<0.001) * * *$ & $0.35(0.17-0.68, \mathrm{p}=0.003) * *$ \\
\hline Local-level managerial agencies & $6(9.7)$ & $56(90.3)$ & $0.92(0.34-2.75, \mathrm{p}=0.871)$ & $0.96(0.34-2.95, \mathrm{p}=0.936)$ \\
\hline \multicolumn{5}{|l|}{ Presence of Chronic Disease } \\
\hline No & $148(16.3)$ & $761(83.7)$ & - & - \\
\hline Yes & $33(23.2)$ & $109(76.8)$ & $0.64(0.42-1.00, \mathrm{p}=0.042) *$ & $0.58(0.37-0.91, \mathrm{p}=0.015) *$ \\
\hline
\end{tabular}

$\phi$ Odds Ratios were obtained by multivariate logistic regression adjusted for gender, professional categories, health facility types and presence of chronic disease

$*$ p-value $<0.05$ at the $5 \%$ level of significance

$* *$ p-value $<0.01$ at the $5 \%$ level of significance 
$* * *$ p-value $<0.001$ at the $5 \%$ level of significance

Table 3: Factors Associated with Self- reported Perception of Government Response to COVID-19 Pandemic

\begin{tabular}{|c|c|c|c|c|}
\hline $\begin{array}{l}\text { Self-reported perception of } \\
\text { government response }\end{array}$ & $\begin{array}{c}\text { Unsatisfactory } \\
\text { Government } \\
\text { response } \\
(n=668) \\
\end{array}$ & $\begin{array}{c}\text { Satisfactory } \\
\text { Government } \\
\text { response } \\
(\mathbf{n}=383)\end{array}$ & OR (univariable) & OR (multivariable) ${ }^{\phi}$ \\
\hline \multicolumn{5}{|l|}{ Ethnicity } \\
\hline Brahmin/Chhetri & $367(60.9)$ & $236(39.1)$ & - & - \\
\hline Madhesi/Muslim & $145(69.4)$ & $64(30.6)$ & $0.69(0.49-0.96, \mathrm{p}=0.028) *$ & $1.15(0.70-1.89, \mathrm{p}=0.586)$ \\
\hline Janajati & $115(66.1)$ & $59(33.9)$ & $0.80(0.56-1.13, \mathrm{p}=0.211)$ & $0.96(0.65-1.42, \mathrm{p}=0.846)$ \\
\hline Dalit & $24(70.6)$ & $10(29.4)$ & $0.65(0.29-1.34, \mathrm{p}=0.260)$ & $0.67(0.29-1.46, \mathrm{p}=0.332)$ \\
\hline Other & $17(54.8)$ & $14(45.2)$ & $1.28(0.61-2.64, \mathrm{p}=0.504)$ & $1.13(0.50-2.49, \mathrm{p}=0.770)$ \\
\hline \multicolumn{5}{|l|}{ Professional Category } \\
\hline Doctor & $274(73.9)$ & $97(26.1)$ & - & - \\
\hline Paramedics & $198(64.3)$ & $110(35.7)$ & $1.57(1.13-2.18, \mathrm{p}=0.007)$ & $1.18(0.78-1.79, \mathrm{p}=0.439)$ \\
\hline Nurse/Midwife & $96(55.5)$ & $77(44.5)$ & $2.27(1.55-3.31, \mathrm{p}<0.001) * * *$ & $2.10(1.38-3.18, \mathrm{p}<0.001) * * *$ \\
\hline Public Health Workers & $52(42.6)$ & $70(57.4)$ & $3.80(2.49-5.85, \mathrm{p}<0.001) * * *$ & $1.83(1.07-3.11, \mathrm{p}=0.027) *$ \\
\hline Lab Worker & $30(58.8)$ & $21(41.2)$ & $1.98(1.07-3.60, \mathrm{p}=0.027)$ & $1.52(0.79-2.90, p=0.207)$ \\
\hline Other & $18(69.2)$ & $8(30.8)$ & $1.26(0.50-2.89, \mathrm{p}=0.606)$ & $1.37(0.52-3.38, \mathrm{p}=0.506)$ \\
\hline \multicolumn{5}{|l|}{ Province } \\
\hline Bagmati Province & $147(72.1)$ & $57(27.9)$ & - & - \\
\hline Province 1 & $136(70.5)$ & $57(29.5)$ & $1.08(0.70-1.67, p=0.726)$ & $0.99(0.62-1.59, \mathrm{p}=0.976)$ \\
\hline Province 2 & $113(72.4)$ & $43(27.6)$ & $0.98(0.61-1.56, \mathrm{p}=0.937)$ & $0.88(0.48-1.61, \mathrm{p}=0.680)$ \\
\hline Gandaki Province & $42(60.9)$ & $27(39.1)$ & $1.66(0.93-2.93, \mathrm{p}=0.083)$ & $1.69(0.92-3.11, \mathrm{p}=0.090)$ \\
\hline Province 5 & $96(62.7)$ & $57(37.3)$ & $1.53(0.98-2.40, \mathrm{p}=0.062)$ & $1.48(0.92-2.40, \mathrm{p}=0.105)$ \\
\hline Karnali Province & $46(41.4)$ & $65(58.6)$ & $3.64(2.25-5.96, \mathrm{p}<0.001) * * *$ & $2.62(1.52-4.53, \mathrm{p}=0.001) * *$ \\
\hline Sudurpaschim Province & $88(53.3)$ & $77(46.7)$ & $2.26(1.47-3.49, \mathrm{p}<0.001) * * *$ & $1.72(1.06-2.80, \mathrm{p}=0.030) *$ \\
\hline
\end{tabular}




\begin{tabular}{|c|c|c|c|c|}
\hline $\begin{array}{l}\text { Self-reported perception of } \\
\text { government response }\end{array}$ & $\begin{array}{l}\text { Unsatisfactory } \\
\text { Government } \\
\text { response } \\
(n=668) \\
\end{array}$ & $\begin{array}{c}\text { Satisfactory } \\
\text { Government } \\
\text { response } \\
(n=383) \\
\end{array}$ & OR (univariable) & OR (multivariable) ${ }^{\phi}$ \\
\hline \multicolumn{5}{|l|}{ Type of Health Facility } \\
\hline $\begin{array}{l}\text { Federal and Provincial managerial } \\
\text { agencies }\end{array}$ & $53(39.6)$ & $81(60.4)$ & - & - \\
\hline Teaching Hospitals & $135(70.7)$ & $56(29.3)$ & $0.27(0.17-0.43, \mathrm{p}<0.001) * * *$ & $0.52(0.29-0.93, \mathrm{p}=0.027) *$ \\
\hline Public Hospitals & $168(70.0)$ & $72(30.0)$ & $0.28(0.18-0.43, \mathrm{p}<0.001) * * *$ & $0.41(0.24-0.70, \mathrm{p}=0.001) * *$ \\
\hline Private Hospitals & $90(68.2)$ & $42(31.8)$ & $0.31(0.18-0.50, \mathrm{p}<0.001) * * *$ & $0.52(0.28-0.94, \mathrm{p}=0.032)$ \\
\hline Local public health facilities & $196(67.1)$ & $96(32.9)$ & $0.32(0.21-0.49, \mathrm{p}<0.001) * * *$ & $0.49(0.30-0.81, \mathrm{p}=0.005) * *$ \\
\hline Local-level managerial agencies & $26(41.9)$ & $36(58.1)$ & $0.91(0.49-1.68, \mathrm{p}=0.752)$ & $1.12(0.58-2.20, \mathrm{p}=0.742)$ \\
\hline \multicolumn{5}{|l|}{ Knowledge about COVID-19 $†$} \\
\hline Inadequate & $154(85.1)$ & $27(14.9)$ & - & - \\
\hline Adequate & $514(59.1)$ & $356(40.9)$ & $3.95(2.61-6.20, \mathrm{p}<0.001) * * *$ & $3.86(2.51-6.16, \mathrm{p}<0.001) * * *$ \\
\hline
\end{tabular}

${ }^{\phi}$ Odds Ratios were obtained by multivariate logistic regression adjusted for Ethnicity, Professional category, Province, type of health facility, and health worker perceived knowledge of COVID-19

$\dagger$ Knowledge about COVID-19 was self-reported; a combined score above average was regarded as "Adequate" knowledge and a score below or equal to the average was considered "Inadequate".

* Self-reported perception of government response during COVID-19 pandemic was self-reported; a combined score above average was regarded as "Satisfactory perception" of knowledge and a score below or equal to the average was considered "Unsatisfactory perception"

$*$ p-value $<0.05$ at the $5 \%$ level of significance

$* *$ p-value $<0.01$ at the $5 \%$ level of significance

$* * *$ p-value $<0.001$ at the $5 \%$ level of significance 


\begin{tabular}{|c|c|c|c|c|}
\hline Perceived Willingness to work & $\begin{array}{l}\text { Unwilling to work } \\
\qquad(\mathrm{n}=377)\end{array}$ & $\begin{array}{l}\text { Willing to work } \\
(n=674)\end{array}$ & $\begin{array}{l}\text { OR (univariable) } \\
\text { (95\% CI, p-value) }\end{array}$ & $\begin{array}{l}\text { OR (multivariable) } \\
\left(95 \% \text { CI, p-value) }^{\phi}\right.\end{array}$ \\
\hline \multicolumn{5}{|l|}{ Ethnicity } \\
\hline Brahmin/Chhetri & $203(33.7)$ & $400(66.3)$ & - & - \\
\hline Madhesi/Muslim & $89(42.6)$ & $120(57.4)$ & $0.68(0.50-0.95, \mathrm{p}=0.021) *$ & $1.11(0.69-1.80, \mathrm{p}=0.659)$ \\
\hline Janajati & $69(39.7)$ & $105(60.3)$ & $0.77(0.55-1.10, p=0.145)$ & $0.90(0.62-1.31, p=0.575)$ \\
\hline Dalit & $7(20.6)$ & $27(79.4)$ & $1.96(0.88-4.95, \mathrm{p}=0.121)$ & $1.74(0.76-4.53, \mathrm{p}=0.215)$ \\
\hline Other & $9(29.0)$ & $22(71.0)$ & $1.24(0.58-2.89, \mathrm{p}=0.595)$ & $0.97(0.43-2.36, p=0.945)$ \\
\hline \multicolumn{5}{|l|}{ Professional Category } \\
\hline Doctor & $191(51.5)$ & $180(48.5)$ & - & - \\
\hline Paramedics & $83(26.9)$ & $225(73.1)$ & $2.88(2.09-3.99, \mathrm{p}<0.001) * * *$ & $2.52(1.79-3.58, \mathrm{p}<0.001) * * *$ \\
\hline Nurse/Midwife & $52(30.1)$ & $121(69.9)$ & $2.47(1.69-3.64, \mathrm{p}<0.001) * * *$ & $2.09(1.40-3.17, \mathrm{p}<0.001) * * *$ \\
\hline Public Health Workers & $28(23.0)$ & $94(77.0)$ & $3.56(2.26-5.77, \mathrm{p}<0.001) * * *$ & $2.40(1.47-4.01, \mathrm{p}=0.001) * *$ \\
\hline Lab Worker & $11(21.6)$ & $40(78.4)$ & $3.86(1.98-8.11, \mathrm{p}<0.001) * * *$ & $3.54(1.77-7.61, \mathrm{p}=0.001) * *$ \\
\hline Other & $12(46.2)$ & $14(53.8)$ & $1.24(0.56-2.79, \mathrm{p}=0.600)$ & $1.24(0.54-2.89, \mathrm{p}=0.609)$ \\
\hline \multicolumn{5}{|l|}{ Province } \\
\hline Bagmati Province & $90(44.1)$ & $114(55.9)$ & - & - \\
\hline Province 1 & $72(37.3)$ & $121(62.7)$ & $1.33(0.89-1.99, \mathrm{p}=0.168)$ & $1.18(0.77-1.81, \mathrm{p}=0.446)$ \\
\hline Province 2 & $71(45.5)$ & $85(54.5)$ & $0.95(0.62-1.44, \mathrm{p}=0.792)$ & $0.83(0.47-1.45, \mathrm{p}=0.510)$ \\
\hline Gandaki Province & $29(42.0)$ & $40(58.0)$ & $1.09(0.63-1.90, \mathrm{p}=0.762)$ & $1.24(0.69-2.22, \mathrm{p}=0.473)$ \\
\hline Province 5 & $64(41.8)$ & $89(58.2)$ & $1.10(0.72-1.68, p=0.666)$ & $0.87(0.56-1.37, p=0.554)$ \\
\hline Karnali Province & $17(15.3)$ & $94(84.7)$ & $4.37(2.48-8.06, \mathrm{p}<0.001) * * *$ & $2.96(1.62-5.64, \mathrm{p}=0.001) * *$ \\
\hline Sudurpaschim Province & $34(20.6)$ & $131(79.4)$ & $3.04(1.92-4.90, \mathrm{p}<0.001) * * *$ & $2.10(1.28-3.48, \mathrm{p}=0.004) * *$ \\
\hline \multicolumn{5}{|l|}{ Presence of Chronic Disease } \\
\hline No & $313(34.4)$ & $596(65.6)$ & - & - \\
\hline
\end{tabular}




\begin{tabular}{|c|c|c|c|c|}
\hline Perceived Willingness to work & $\begin{array}{l}\text { Unwilling to work } \\
\qquad(\mathbf{n}=\mathbf{3 7 7})\end{array}$ & $\begin{array}{l}\text { Willing to work } \\
\qquad(n=674)\end{array}$ & $\begin{array}{l}\text { OR (univariable) } \\
\text { (95\% CI, p-value) }\end{array}$ & $\begin{array}{l}\text { OR (multivariable) } \\
(95 \% \text { CI, p-value) }\end{array}$ \\
\hline Yes & $64(45.1)$ & $78(54.9)$ & $0.64(0.45-0.92, \mathrm{p}=0.015) *$ & $0.67(0.46-0.99, \mathrm{p}=0.043) *$ \\
\hline \multicolumn{5}{|l|}{$\begin{array}{l}\text { HWs having family members who } \\
\text { need care }\end{array}$} \\
\hline No & $120(31.5)$ & $261(68.5)$ & - & - \\
\hline Yes & $257(38.4)$ & $413(61.6)$ & $0.74(0.57-0.96, p=0.026) *$ & $0.72(0.54-0.95, \mathrm{p}=0.021) *$ \\
\hline \multicolumn{5}{|l|}{$\begin{array}{l}\text { Perceived Knowledge about } \\
\text { COVID-19 }\end{array}$} \\
\hline Inadequate & $86(47.5)$ & $95(52.5)$ & - & - \\
\hline Adequate & $291(33.4)$ & $579(66.6)$ & $1.80(1.30-2.49, \mathrm{p}<0.001) * * *$ & $1.81(1.27-2.58, \mathrm{p}=0.001) * *$ \\
\hline \multicolumn{5}{|l|}{$\begin{array}{l}\text { Perception of government } \\
\text { response }^{\ddagger}\end{array}$} \\
\hline Unsatisfactory perception & $264(39.5)$ & $404(60.5)$ & - & - \\
\hline Satisfactory Perception & $113(29.5)$ & $270(70.5)$ & $1.56(1.20-2.05, \mathrm{p}=0.001) * *$ & $1.12(0.83-1.51, \mathrm{p}=0.448)$ \\
\hline
\end{tabular}

${ }^{\phi}$ Odds Ratios were obtained by multivariate logistic regression adjusted for Ethnicity, Professional category, Province, Presence of Chronic Disease, health workers with family members requiring care, perceived knowledge of COVID-19, and perception of government response.

$\dagger$ Knowledge about COVID-19 was self-reported; a combined score above average was regarded as "Adequate" knowledge and a score below or equal to the average was considered "Inadequate".

"Perception of government response during COVID-19 pandemic was self-reported; a combined score above average was regarded as "Satisfactory perception" of knowledge and score below or equal to the average was considered "Unsatisfactory Perception".

$*$ p-value $<0.05$ at the $5 \%$ level of significance

$* *$ p-value $<0.01$ at the $5 \%$ level of significance

$* * *$ p-value $<0.001$ at the $5 \%$ level of significance 